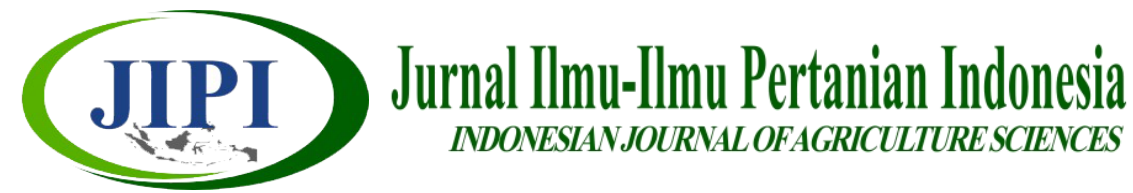

\title{
KERAGAAN BUAH 26 GENOTIPE MELON (Cucumis melo L.) PADA SISTEM BUDIDAYA HIDROPONIK SUMBU
}

\author{
Helfi Eka Saputra ${ }^{1 *}$, Umi Salamah ${ }^{1}$, Welly Herman ${ }^{2}$, Marlina Mustafa ${ }^{3}$ \\ ${ }^{1}$ Program Studi Agroekoteknologi, Fakultas Pertanian, Universitas Bengkulu \\ ${ }^{2}$ Program Studi Ilmu Tanah, Fakultas Pertanian, Universitas Bengkulu \\ ${ }^{3}$ Program Studi Agroteknologi, Fakultas Pertanian, Perikanan dan Peternakan, Universitas Sembilanbelas November \\ Kolaka \\ * Corresponding Author: hesaputra@unib.ac.id
}

\begin{abstract}
[FRUIT PERFORMANCE OF 26 GENOTYPES OF MELON (Cucumis melo L.) IN WICK HYDROPONIC CULTIVATION SYSTEMS]. Fruit performance is determining quality factor for melon fruit. This research aimed to obtain the melon genotype which has the best fruit quality by the cultivation of the wick hydroponic system. The research was conducted from June to September 2020 in the greenhouse of the Agronomy Laboratory, Bengkulu University. The study was compiled with a single-factor of the melon genotypes using randomized complete block design (RCBD) with two replications. The genotypes were G23, G27, G28, G29, G38, G39, G40, G41, G42, G43, G45, G46, G47, G48, G49, G52, G53, G55, G57, G58, G60, G62, G63, G64, G65, and G66. The best genotypes for fruit length characters were G28 and G42. The best genotypes for fruit diameter character were G52, G58, G60, G64, and G66. The best genotype for fruit thickness character was G43. The best genotype for total dissolved solids character was G45. The best genotypes for fruit weight characters were G58, G66, and G60.
\end{abstract}

Keyword: fruit quality, genotype, hydroponic, melon

\begin{abstract}
ABSTRAK
Tampilan buah menjadi faktor penentu kualitas buah melon. Tujuan penelitian adalah untuk mendapatkan genotipe melon yang memiliki kualitas buah terbaik dengan budidaya system hidroponik sumbu. Penelitian dilaksanakan pada bulan Juni sampai September 2020 di rumah kaca Laboratorium Agronomi Universitas Bengkulu. Penelitian disusun dengan rancangan kelompok lengkap teracak (RKLT) faktor tunggal yaitu genotipe dengan dua ulangan. Genotipe yang digunakan yaitu G23, G27, G28, G29, G38, G39, G40, G41, G42, G43, G45, G46, G47, G48, G49, G52, G53, G55, G57, G58, G60, G62, G63, G64, G65 dan G66. Genotipe terbaik untuk karakter panjang buah adalah G28 dan G42. Genotipe terbaik untuk karakter diameter buah adalah G52, G58, G60, G64 dan G66. Genotipe terbaik untuk karakter ketebalan buah adalah G43. Genotipe terbaik untuk karakter padatan total terlarut adalah genotipe G45. Genotipe terbaik untuk karakter bobot buah adalah G58, G66 dan G60.
\end{abstract}

Kata kunci: genotipe, hidroponik, kualitas buah melon 


\section{PENDAHULUAN}

Melon merupakan komoditi hortikulura yang memiliki nilai ekonomi cukup tinggi dan menguntungkan untuk diusahakan sebagai sumber pendapatan petani. Melon memiliki rasa yang manis dan merupakan sumber vitamin dalam pola menu makanan masyarakat Indonesia serta bahan baku industri olahan. Harga jual yang tinggi pada buah melon menjadikan melon sebagai komoditas bisnis unggulan.

Luas panen melon di Provinsi Bengkulu mengalami penurunan sebesar 9,38 persen pada tahun 2019. Penurunan luas panen ini berbanding lurus dengan produktivitas melon di Provinsi Bengkulu yang mengalami penurunan dari $63,46 \mathrm{kw} / \mathrm{ha}$ menjadi 44,14 kw/ha sehingga produksi melon di Provinsi Bengkulu untuk tahun 2019 mengalami penurunan sebesar 22,42 persen dibandingkan dengan tahun 2018 (BPS, 2019). Oleh karena itu tanaman melon ini sangat potensial untuk dibudidayakan khususnya di Provinsi Bengkulu. Salah satu bentuk sistem budidaya tanaman melon adalah dengan menggunakan sistem hidroponik sumbu.

Sistem hidroponik sumbu (wick) merupakan suatu cara bertanam hidroponik yang membutuhkan sumbu sebagai perantara nutrisi. Sistem ini bersifat pasif, karena tidak ada bagian-bagian yang bergerak. Sistem hidroponik sumbu bekerja dengan prinsip membagikan nutrisi tanaman melalui bantuan sumbu yang disambungkan dari netpot ke bak nutrisi. Sistem hidroponik sumbu memiliki keunggulan yaitu tidak memerluan perawatan khusus, mudah dalam merakit, dapat dipindahkan, dan cocok pada lahan terbatas (Marlina et al., 2015). Menurut Simbolon $\&$ Suryanto (2018) bahwa nutrisi berperan penting dalam menghasilkan keragaan melon yang berkualitas dalam budidaya secara hidroponik. Selain larutan nutrisi, faktor lain yang mempengaruhi pertumbuhan tanaman yaitu media tanam (Bariyyah et al., 2015). Salah satu media tanam yang dapat digunakan yaitu pasir. Menurut Christy (2020), penggunaan media tanam pasir memberikan pengaruh terbaik terhadap perkembangan melon.

Kriteria buah melon yang diinginkan oleh masyarakat adalah bobot buah dan kadar gula tinggi (Huda et al., 2017). Menurut Huda \& Daryono (2013), ciri melon yang unggul adalah rasa manis, ukuran buah besar dan daya simpan yang lama. Khumaero et al. (2014) melaporkan bahwa semakin tinggi bobot buah maka semakin tebal daging buah dan rasa buah semakin manis. Menurut Manohar \& Murthy (2012) bahwa tebal daging buah merupakan karakter buah penting karena berkorelasi positif dengan daya simpan. Karakter panjang buah dan diameter buah yang besar menyebabkan bobot buah semakin berat (Daryono \& Nofriarno, 2018).
Berdasarkan uraian tersebut maka perlu melakukan pengujian 26 genotipe melon dengan sistem hidroponik sumbu khususnya untuk karakter-karakter yang berhubungan dengan kualitas buah. Penelitian ini bertujuan untuk mendapatkan genotipe terbaik melon pada masing-masing karakter buah dengan budidaya sistem hidroponik sumbu.

\section{METODE PENELITIAN}

Penelitian dilaksanakan di rumah kaca Laboratorium Agronomi Universitas Bengkulu dari bulan Juni sampai September 2020. Genotipe melon yang digunakan sebanyak 26 genotipe yang berasal dari eksplorasi dan introduksi dari berbagai daerah yaitu G23, G27, G28, G29, G38, G39, G40, G41, G42, G43, G45, G46, G47, G48, G49, G52, G53, G55, G57, G58, G60, G62, G63, G64, G65 dan G66. Penelitian disusun menggunakan Rancangan Acak Kelompok Lengkap (RAKL) faktor tunggal yaitu genotipe melon dengan dua ulangan sehingga terdapat 52 satuan percobaan.

Penanaman melon dilakukan secara hidroponik sistem sumbu menggunakan pasir sebagai media tanam. Masing-masing polibag diberi sumbu yang berasal dari kain flannel, selanjutnya pasir gunung dimasukkan ke dalam polibag yang sudah ada sumbu. Setiap polibag berisi pasir dan ada sumbu diletakkan di atas ember plastik berisi larutan hara dengan memastikan sumbu yang keluar dari polibag menyentuh dasar ember plastik. Setelah semua media tanam siap selanjutnya dilakukan penanaman benih melon sebanyak 2 benih secara langsung di setiap media tanam tersebut. Setelah 1 minggu setelah tanam (mst) dipilih tanaman melon yang memiliki pertumbuhan yang terbaik.

Larutan hara yang digunakan adalah $\mathrm{AB}$ mix. Pembuatan larutan hara dengan membuat stok A dan stok B secarah terpisah. Setelah larutan stok dibuat maka selanjutnya dibuat larutan hara siap pakai untuk budidaya melon. Konsentrasi hara yang diberikan adalah $5 \mathrm{~mL} / \mathrm{L}$ stok A $+5 \mathrm{~mL} / \mathrm{L}$ stok B. Pemberian hara dilakukan setiap dua hari sekali ke dalam ember plastik sampai penuh. Pengendalian organisme pengganggu tanaman dilakukan secara berkala dengan menyemprotkan insektisida berbahan aktif Diapentiuron $500 \mathrm{~g} / \mathrm{L}$ konsentrasi $1 \mathrm{~mL} / \mathrm{L}$ dan fungisida berbahan aktif Azoksistrobin $200 \mathrm{~g} / \mathrm{L}$ dan Difenokonazol $125 \mathrm{~g} / \mathrm{L}$ konsentrasi $1 \mathrm{~mL} / \mathrm{L}$ setiap minggu sejak tanaman berumur dua minggu setelah tanam.

Karakter buah yang diamati meliputi panjang buah, diameter buah, tebal daging buah, padatan total terlarut dan bobot buah. Data yang diperoleh dianalisis secara statistika dengan sidik ragam dan dilanjutkan dengan uji jarak berganda Duncan 5\%. 


\section{HASIL DAN PEMBAHASAN}

Evaluasi 26 genotipe melon memiliki panjang buah yang bervariasi dengan rentang berkisar 8,85 $\mathrm{cm}-18,20 \mathrm{~cm}$. Genotipe yang panjang buah yang terbaik adalah G42 $(18,20 \mathrm{~cm})$ dan G28 $(18,00 \mathrm{~cm})$ dan berbeda nyata dengan 15 genotipe lainnya (Tabel 1). Zulfikri et al. (2015) melaporkan bahwa enam varietas melon yang diuji memiliki panjang buah berkisar $11,24 \mathrm{~cm}-14,02 \mathrm{~cm}$. Selanjutnya Huda et al. (2017) juga melaporkan bahwa pengujian beberapa genotipe melon mendapatkan panjang buah berkisar $10,48 \mathrm{~cm}$ $-15,80 \mathrm{~cm}$. Berdasarkan beberapa penelitian tersebut bahwa genotipe yang diuji pada penelitian ini memiliki panjang buah dalam rentang yang sama bahkan ada yang melebihi yaitu G28, G29, G41 dan G42.

Diameter buah melon komersil yang ditanam memiliki nilai berkisar 11,62 cm - 14,80 cm (Zulfikri et al., 2015). Huda et al. (2015) melaporkan bahwa diameter buah berkorelasi positif terhadap panjang buah sehingga semakin panjang buah maka akan diikuti dengan semakin besar diameter buah. Hasil penelitian tersebut berbeda dengan peneliti ini yaitu genotipe yang memiliki diameter buah yang besar tidak diikuti dengan panjang buah yang panjang seperti G52. Karakter panjang buah dan diameter buah berkaitan erat dengan bentuk buah. Genotipe melon yang memiliki panjang buah yang panjang dan tidak diikuti dengan diameter buah yang besar akan memiliki bentuk buah yang lonjong. Berbeda halnya dengan genotipe yang memiliki ukuran panjang buah dan diameter buah yang relatif sama maka bentuk buah menjadi bulat. Genotipe yang memiliki panjang buah terpanjang dan tidak diikuti dengan diameter buah yang besar adalah G28, G29, G41 dan G42 (Tabel 1) sehingga tergolong genotipe yang memiliki bentuk buah lonjong. Selain empat genotipe tersebut, 22 genotipe lainnya memiliki panjang buah dan diameter buah yang relatif sama sehingga tergolong genotipe yang memiliki bentuk buah bulat (Tabel 1).

Ketebalan daging buah merupakan salah satu karakter penting yang dijadikan untuk menentukan kualitas buah. Tanaman melon yang memiliki ketebalan daging buah yang tebal lebih disukai masyarakat karena bagian ini yang dapat dikonsumsi. Ketebalan daging buah 26 genotipe melon yang diteliti berkisar $1,6 \mathrm{~cm}-3,7 \mathrm{~cm}$ (Tabel 1). Khumaero et al. (2014) melaporkan bahwa varietas melon komersil yang ditanam memiliki ketebalan daging buah $2,9 \mathrm{~cm}-3,2$ cm. Menurut Sari et al. (2019) kebanyakan konsumen menyukai buah dengan ketebalan yang tinggi. Huda et al. (2017) melaporkan bahwa tebal daging buah berkorelasi positif terhadap diameter buah. Berbeda halnya dengan penelitian Huda et al. (2017), pada penelitian ini genotipe yang memiliki ketebalan daging buah yang besar adalah G43, namun diameter buahnya bukan yang terbesar. Hal ini diduga karena ruang buah (tempat mengumpul biji) yang besar sehingga mengurangi ketebalan daging buah meskipun diameter buah besar.

Kandungan padatan total terlarut pada genotipe yang diuji berkisar 5,65 ${ }^{\circ}$ briks-12,45 ${ }^{\circ}$ briks (Tabel 2). Keragaman genotipe untuk karakter kandungan padatan total terlarut lebih tinggi dibandingkan dengan karakter lainnya. Hal ini dibuktikan dengan banyaknya notasi yang terbentuk dari uji jarak berganda Duncan (Tabel 2). Makful et al. (2017), Amzeri et al. (2020), Anggara et al. (2020) dan Nurjanah et al. (2020) melaporkan bahwa nilai padatan total terlarut melon berkisar 9,3 ${ }^{\circ}$ briks-16,0 ${ }^{\circ}$ briks. Berdasarkan penelitian tersebut, terdapat 9 genotipe yang memiliki nilai padatan total terlarut berkisar $9,3^{\circ}$ briks-16,0 obriks. yaitu G39, G45, G48, G49, G52, G58, G60, G65, dan G66. Genotipe yang memiliki kandungan padatan total terlarut yang tertinggi pada penelitian ini adalah G45 dan lebih tinggi dibandingkan G23, G27, G28, G29, G38, G40, G41, G42, G43, G47, G53, G55, G57, G62, G63, G64. Selanjutnya Huda et al. (2018) juga melaporkan kandungan kadar gula melon berkisar $3,5^{\circ}$ briks - 5,5 ${ }^{\circ}$ briks, sehingga genotipe-genotipe yang diuji lebih baik kandungan gulanya dibandingkan penelitian ini. Kandungan padatan total terlarut menunjukkan kemanisan buah. Park et al. (2018) melaporkan bahwa kemanisan buah merupakan karakter yang menjadika preferensi konsumen dalam menentukan kualitas buah. Semakin tinggi kemanisan buah maka keragaan semakin unggul (Sari et al., 2019). Faktor-faktor yang mempengaruhi kandungan padatan total terlarut di antaranya tingkat ketuaan buah saat panen, jarak tanam, jenis pupuk dan waktu pemupukan (Makful et al., 2017).

Bobot buah menjadi indikator penting dalam melakukan budidaya tanaman melon. Semakin besar bobot buah melon maka akan menjadikan semakin tinggi produksinya. Keragaan bobot buah pada penelitian ini berkisar 301,4 g-1079,7 g (Tabel 2). Genotipe G58, G66 dan G60 merupakan genotipe yang memiliki bobot buah lebih dari $1000 \mathrm{~g}$ dan lebih tinggi dibandingkan G28, G38, G39, G43, G45, G47, G48, G53, G55, G57, G65, sedangkan 12 genotipe lain berbeda tidak nyata. Hasil penelitian ini sama dengan penelitian yang dilakukan Khumaero et al. (2014) dan Iqbal et al. (2019) yaitu beberapa genotipe melon yang diuji memiliki bobot buah 653,3 g-926,5 g (melon hasil perakitan) dan 510,9 g-1494,1 g (melon komersil). Genotipe G58, G66 dan G60 juga memiliki panjang buah, diameter buah dan ketebalan buah yang lebih dari beberapa genotipe lainnya dan tergolong besar. Hasil ini sesuai dengan penelitian Daryono \& Nofriarno (2018) yaitu bobot buah yang berat diperoleh dari buah yang memiliki panjang dan diameter yang besar. Ada empat ukuran buah yang ditentukan berdasarkan bobot buah yaitu ukuran $1(>2,5$ $\mathrm{kg})$, ukuran $2(>2-2,5 \mathrm{~kg})$, ukuran $3(>1,5-2 \mathrm{~kg})$ 
dan ukuran $4(<1,5 \mathrm{~kg})(\mathrm{BSN}, 2013)$. Berdasarkan standarisasi tersebut maka semua genotipe melon memiliki bobot buah ukuran 4 . Bobot buah yang tergolong kecil tidak selalu menjadi kekurangan dan kelemahan dari kualitas buah karena sebagian masyarakat sudah popular dengan melon ukuran kecil yang memiliki keuntungan yaitu dapat dihabiskan dalam satu atau dua kesempatan (Bezirganoglu et al., 2013).।

Tabel 1. Keragaan panjang buah, diameter buah dan tebal daging buah pada 26 genotipe melon

\begin{tabular}{|c|c|c|c|c|c|c|}
\hline \multirow[t]{2}{*}{ Genotipe } & \multicolumn{2}{|c|}{$\begin{array}{c}\text { Panjang } \\
\text { Buah }\end{array}$} & \multicolumn{2}{|c|}{$\begin{array}{c}\text { Diameter } \\
\text { Buah }\end{array}$} & \multicolumn{2}{|c|}{$\begin{array}{c}\text { Tebal Daging } \\
\text { Buah }\end{array}$} \\
\hline & \multicolumn{6}{|c|}{$\cdots \mathrm{cm} \cdots$} \\
\hline G23 & 15,85 & abcd & 9,95 & abcdef & 2,3 & defg \\
\hline G27 & 12,1 & abcd & 11 & abcdef & 2,85 & abcde \\
\hline G28 & 18 & a & 7,5 & f & 1,75 & fd \\
\hline G29 & 17,75 & $a b$ & 8,35 & cdef & 2,1 & efg \\
\hline G38 & 9,95 & cd & 7,95 & cdef & 1,65 & g \\
\hline G39 & 9,95 & cd & 9,95 & abcdef & 2,7 & bcde \\
\hline $\mathrm{G} 40$ & 12,65 & abcd & 11,9 & $a b c$ & 2,6 & bcdef \\
\hline G41 & 16,35 & $a b c$ & 8,75 & bcdef & 2,35 & cdefg \\
\hline $\mathrm{G} 42$ & 18,2 & a & 8,75 & bcdef & 2,2 & efg \\
\hline G43 & 10,65 & cd & 10,1 & abcdef & 3,7 & a \\
\hline $\mathrm{G} 45$ & 8,85 & d & 10,5 & abcdef & 2,5 & cdefg \\
\hline G46 & 11,9 & abcd & 11,9 & $a b c$ & 3,2 & abcd \\
\hline G47 & 8,85 & d & 7,75 & ef & 1,75 & $\mathrm{fg}$ \\
\hline $\mathrm{G} 48$ & 10,95 & bod & 11,5 & abcd & 2,45 & cdefg \\
\hline $\mathrm{G} 49$ & 10,2 & $c d$ & 11,3 & abcde & 2,75 & bcde \\
\hline G52 & 10,2 & $c d$ & 12,4 & a & 3,25 & $a b c$ \\
\hline G53 & 10,55 & cd & 10,2 & abcdef & 2,45 & cdefg \\
\hline G55 & 9,8 & $c d$ & 10,6 & abcdef & 2,7 & bcde \\
\hline G57 & 10,35 & cd & 7,6 & f & 1,7 & $\mathrm{fg}$ \\
\hline G58 & 10,95 & bed & 13 & a & 3,2 & abcd \\
\hline G60 & 11,4 & abcd & 12,9 & a & 3,25 & $a b c$ \\
\hline G62 & 10,6 & $\mathrm{~cd}$ & 11,7 & $a b c$ & 2,8 & abcde \\
\hline G63 & 11,4 & abcd & 12,2 & $a b$ & 2,9 & abcde \\
\hline G64 & 10,4 & $c d$ & 12,7 & a & 2,45 & cdefg \\
\hline G65 & 9,75 & cd & 11,3 & abcde & 2,95 & abcde \\
\hline G66 & 12,4 & abcd & 12,9 & a & 3,5 & $a b$ \\
\hline eteran & $\overline{A n \pi}$ & ר-7 & 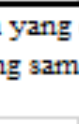 & 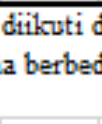 & $\operatorname{ggan} 1$ & horof \\
\hline
\end{tabular}

Tabel 2. Keragaan padatan total terlarut dan bobot buah pada 26 genotipe melon

\begin{tabular}{|c|c|c|}
\hline Genotipe & $\begin{array}{c}\text { Padatan Total } \\
\text { Terlarut }\end{array}$ & Bobot Buah \\
\hline & --"briks-- & -g-- \\
\hline G23 & 7,7 defghij & 801,2 abcdef \\
\hline G27 & 8,9 cdefghi & 817,6 abcde \\
\hline G28 & 5,65 j & 532,5 defgh \\
\hline G29 & 6,9 fghij & 856,2 abcd \\
\hline G38 & 7,75 defghij & 414,4 fgh \\
\hline G39 & 10 abcdef & 578,8 defgh \\
\hline G40 & 6,25 hij & 994,3 abc \\
\hline G41 & 5,9 i & 973 abc \\
\hline G42 & 6,9 fghij & 852,7 abcd \\
\hline G43 & 8,15 cdefghij & 580,2 defgh \\
\hline G45 & 12,45 a & 429,6 efgh \\
\hline G46 & 9,8 abcdefg & 893,1 abcd \\
\hline G47 & 5,4 j & 301,4 h \\
\hline G48 & 10,2 abcde & 629,2 cdefgh \\
\hline G49 & 10,6 abcd & 703,6 abcdefg \\
\hline G52 & 11 abc & 847 abcd \\
\hline G53 & 7,75 defghij & 548,5 defgh \\
\hline G55 & 8,55 cdefghij & 608,7 cdefgh \\
\hline G57 & 7,75 defghij & 324,3 gh \\
\hline G58 & 10,1 abcde & 1079,7 a \\
\hline G60 & 12,1 ab & 1024,8 ab \\
\hline G62 & 7,25 efghij & 729,4 abcdef \\
\hline G63 & 9,15 bcdefgh & 894,8 abcd \\
\hline G64 & 6,8 ghij & 788,1 abcdef \\
\hline G65 & 11 abc & 683,7 bcdefgh \\
\hline G66 & 10,1 abcde & 1077,6 a \\
\hline pang sama pada kolom yang sama berbeda tidak nyata \\
\hline $5 \%$ & \\
\hline
\end{tabular}

\section{KESIMPULAN}

Genotipe terbaik untuk karakter panjang buah adalah G28 dan G42. Genotipe terbaik untuk karakter diameter buah adalah G52, G58, G60, G64 dan G66. Genotipe terbaik untuk karakter ketebalan buah adalah G43. Genotipe terbaik untuk karakter padatan total terlarut adalah genotipe G45. Genotipe terbaik untuk karakter bobot buah adalah G58, G66 dan G60. 


\section{SANWACANA}

Ucapan terima kasih disampaikan kepada Fakultas Pertanian Universitas Bengkulu atas dana penelitian berdasarkan Kontrak No. 2400/UN30.11/PM/2020. Terima kasih juga disampaikan kepada pihak-pihak yang membantu pelaksanaan penelitian.

\section{DAFTAR PUSTAKA}

Amzeri, A., Badami, K., Khoiri, S., Umam, A.S., Wahid, N. \& Nurlaella S. (2020). Karakter morfologi, heritabilitas, dan indeks seleksi terboboti beberapa generasi F1 melon (Cucumis melo L.). Jurnal Agro, 7(1), 42-51. DOI: https:// doi.org/10.15575/6244

Anggara, H., Suwarno, W.B., Saptomo, S.K., Gunawan, E., Huda, A.N. \& Setiawan, B.I. (2020). Keragaan lima varietas melon (Cucumis melo L.) dengan perlakuan irigasi cincin rumah kaca. J. Agron. Indonesia, 48(3), 307-313. DOI: https://doi.org/10.24831/jai.v48i3.32206

Bariyyah, K., Suparjono, S. \& Usmadi. (2015). Pengaruh kombinasi komposisi media organik dan konsentrasi nutrisi terhadap daya hasil tanaman melon (Cucumis melo L.). Planta Tropica Journal of Agro Science, 3(2), 67-72. DOI: http://dx.doi.org/10.18196/pt.2015.041.67-72

BPS. (2019). Produksi Sayur dan Buah Provinsi Bengkulu. http:/bps.go.id. 1 November 2020

BSN. (2013).Melon. Badan Standarisasi Nasional. Jakarta.

Bezirganoglu, I., Hwang, S.Y., Fang, T.J. \& Shaw, F.J. (2013). Transgenic lines of melon (Cucumis melo L. var. makuwa cv. 'Silver Light') expressing antifungal protein and chitinase genes exhibit enhaced resistance to fungal pathogens. PCTOC Journal of Plant Biotechnology 112, 227-237. DOI: https:// doi.org/10.1007/s11240-012-0227-5

Christy, J. (2020). Respon peningkatan produksi buah melon (Cucumis melo L.) secara hidroponik. Agrium, 22(3), 150-156. DOI: https:// doi.org/10.30596/agrium.v22i3.4686

Daryono, B.S. \& Nofriarno, N. (2018). Pewarisan karakter fenotip melon (Cucumis melo L. 'Hikapel Aromatis') hasil persilangan 'Hikapel' dengan 'Hikadi Aromatik'. Biosfera 35 (1), 44 -48. DOI: $\quad$ https://doi.org/10.20884/1.mib. 2018.35.1.586

Huda, A.N., Suwarno W.B. \& Maharijaya, A. (2017). Keragaman genetik karakteristik buah antar 17 genotipe melon (Cucumis melo L.). J. Hort. Indonesia, 8(1), 1-12. DOI: https://doi.org/ 10.29244/jhi.8.1.1-12

Huda, A.N., Suwarno W.B. \& Maharijaya, A. (2018). Respon delapan genotipe melon (Cucumis melo L.) terhadap perlakuan $\mathrm{KNO}_{3}$. J. Hort. Indo- nesia 9 (2), 84-92. DOI: https://doi.org/10. 29244/jhi.9.2.84-92

Huda, I.N. \& Daryono, B.S. (2013). Analisis variasi genetik melon (Cucumis melo L.) kultivar gama melon basket dengan metode random amplified polymorphic DNA. Biogenesis 1(1), 4150.DOI: https://doi.org/10.24252/bio.vlil. 446

Khumaero, W.W., Efendi, D., Suwarno, W.B. \& Sobir. (2014). Evaluasi karakteristik hortikultura empat genotipe melon (Cucumis melo L.) Pusat Kajian Hortikultura Tropika IPB. J. Hort. Indonesia, 5(1), 56-63. DOI: https:// doi.org/10.29244/jhi.5.1.56-63

Iqbal, M., Barchia, M.F. \& Romeida, A. (2019). Pertumbuhan dan hasil tanaman melon (Cucumis melo L.) pada komposisi media tanam dan frekuensi pemupukan yang berbeda. Jurnal Ilmu-Ilmu Pertanian Indonesia, 21(2), 108114. DOI: https://doi.org/10.31186/jipi.21.2. 108-114

Makful., Hendri., Sahlan, Sunyoto \& Kuswandi. (2017). Karakter buah galur melon generasi S6 dan S7. Bul. Plasma Nutfah, 23(1), 1-12.

Manohar, S.H. \& Murthy, H.N. (2012). Estimation of phenotypic divergence in a collection of $\mathrm{Cu}$ cumis melo, including shelf-life of fruit. Scientia Horticulturae, 148, 74-82. DOI: https:// doi.org/10.1016/j.scienta.2012.09.025

Marlina, I., Triyono, S. \& Tusi, A. (2015). Pengaruh media tanam granul dari tanah liat terhadap pertumbuhan sayuran hidroponik sistem sumbu. Teknik Pertanian Lampung 4(2), 143-150.

Nurjanah, E., Sumardi \& Prasetyo. (2020). Pemberian pupuk kandang sebagai pembenah tanah untuk pertumbuhan dan hasil melon (Cucumis melo L.) di Ultisol. Jurnal Ilmu-Ilmu Pertanian Indonesia, 22(1), 23-30. DOI: https://doi.org/ 10.31186/jipi.22.1.23-30

Park, E., Luo, Y., Marine, S. C., Everts, K. L., Micallef, S.A. ,Bolten, S. \& Stommel, J. (2018). Consumer preference and physicochemical evaluation of organically grown melons. Postharvest Biology and Technology, 141, 77-85. DOI: https:// doi:10.1016/j.postharvbio. 2018.03.001

Sari, I.P., Saptadi, D. \& Setiyawan, A. (2019). Penampilan 9 calon varietas hibrida melon (Cucumis melo L.). Jurnal Produksi Tanaman, 7(4), 643-651.

Simbolon, S.N. \& Suryanto, A. (2018). Pengaruh interval waktu pemberian nutrisi AB-mix dan metode hidroponik pada tanaman melon (Cucumis melo L.). Jurnal Produksi Tanaman, 6(9), 2372-2381.

Zulfikri., Hayati, E., \& Nasir, M. (2015). Penampilan fenotipik, parameter genetik karakter hasil dan komponen hasil tanaman melon (Cucumis melo). $J$. Floratek 10(2), 1-11. 